\title{
Oxalate-Degrading Bacteria Can Protect Arabidopsis thaliana and Crop Plants Against Botrytis cinerea
}

\author{
Henk-jan Schoonbeek, Anne-Claude Jacquat-Bovet, Fabio Mascher, and Jean-Pierre Métraux \\ Institute of Plant Biology, Department of Biology, University of Fribourg, Route Albert Gockel 3, CH-1700 Fribourg, \\ Switzerland
}

Submitted 20 March 2007. Accepted 14 July 2007.

\begin{abstract}
Botrytis cinerea and Sclerotinia sclerotiorum secrete oxalic acid as a pathogenicity factor with a broad action. Consequently, it should be possible to interfere with the infection process by degrading oxalic acid during the interaction of these pathogens with their hosts. We have evaluated the potential of oxalate-degrading bacteria to protect plants against pathogenic fungi. Such bacteria were isolated from agricultural soil and selected on agar plates with Ca-oxalate as the sole carbon source. Four strains were retained with a medium-to-strong protective activity on Arabidopsis thaliana leaves against $B$. cinerea and $S$. sclerotiorum. They can provide 30 to $70 \%$ protection against fungal infection in different pathosystems, including $B$. cinerea on $A$. thaliana, cucumber, grapevine, and tomato. The oxalatedegrading bacteria induced only some marker genes for common plant signaling pathways for defenses, but protective effects were slightly reduced in A. thaliana mutants impaired in the ethylene and jasmonic acid signaling pathways. More detailed studies on the protective mechanism were performed in ox-strain $\mathrm{B}$, identified as Cupriavidus campinensis, by analysis of transposon-tagged mutants that have a reduced ability to degrade oxalic acid.
\end{abstract}

Additional keywords: biological control, gray mold.

Botrytis cinerea and Sclerotinia sclerotiorum are closely related necrotrophic pathogens, causing large economic losses on a very wide host range (Boland and Hall 1994; Jarvis 1977; Prins et al. 2000). Both are able to produce oxalic acid (Germeier et al. 1994) and, for S. sclerotiorum, it is instrumental for successful infection (Dickman and Mitra 1992; Godoy et al. 1990). Oxalic acid helps these fungi to be pathogenic on a broad variety of host plants as a virulence factor with several functions: i) lowering of the $\mathrm{pH}$, which favors the action of pectolytic enzymes; ii) chelation of bivalent ions in cell walls and, hence, disruption of the plant tissue; and iii) blocking of defense signaling pathways in the plant. It also plays a role in regulation of pathogenicity mechanisms within the fungi (Manteau et al. 2003; Rollins and Dickman 2001). Conse-

Corresponding author: J. P. Métraux; Fax: (+41) 02630097 40; E-mail: Jean-Pierre.Metraux@unifr.ch

Current address of F. Mascher: Agroscope Changins-Wädenswil research station ACW, PO box 1012, CH-1260 Nyon, Switzerland.

*The $\boldsymbol{e}$-Xtra logo stands for "electronic extra" and indicates that Figure 1 appears in color online and two additional figures are published online. quently, it would be interesting to determine the outcome of an infection after interference with oxalic acid levels at the infection site. Biodegradation of oxalic acid previously has been proposed for the control of $S$. sclerotiorum (Dickman and Chet 1998 ) and might also work against $B$. cinerea.

Possible ways to modify oxalic acid levels include the application of agrochemicals or development of engineered crop plants with enhanced ability to degrade oxalic acid. Plant protection compounds may be fungicides that target oxalate production in the pathogen or "buffering" agents. The partial protection by some carbonate salts against $B$. cinerea infection may be related to such a buffering mechanism (Fallik et al. 1997; Gabler and Smilanick 2001). Some transgenic crop plants have been generated that degrade oxalic acid and are more resistant to $S$. sclerotiorum (Donaldson et al. 2001; Livingstone et al. 2005; Thompson et al. 1995). Here, we have exploited the versatility of biological agents to degrade oxalic acid and act as plant protectors. Oxalate-degrading bacteria are known from a wide variety of ecological niches and different taxonomical origins (Sahin 2003). They play important roles in local and global carbon-cycling (Braissant et al. 2002; Jones 1998) and, when present in the guts of mammals, they seem to provide protection against excess oxalate uptake and renal stones (Stewart et al. 2004). Most of the described bacteria use oxalic acid as a carbon or energy source and metabolize it via the oxalyl-CoAdecarboxylase pathway to produce formate and incorporate it in their metabolism (Svedruzic et al. 2005). To find oxalatedegrading bacteria (referred to as ox-strains), we performed a screening on agar plates with Ca-oxalate as the sole carbon source (Aragno and Schlegel 1992) with bacteria isolated from soil and leaf litter, where their presence has been described previously (Sahin 2003). To obtain bacteria that thrive well on plant surfaces, we specifically tried to isolate them from the rhizosphere of plants. After proof-of-concept in the interaction of $B$. cinerea with established host plants, we tested whether the bacteria could be applied easily to various pathosystems, among which was Arabidopsis thaliana, providing an important advantage for research.

Plants rely on a network of defense pathways against pathogens, transmitted by the signaling molecules salicylic acid (SA), ethylene (ET), and jasmonic acid (JA), among others (McDowell and Dangl 2000). The role of various plant defense pathways in the observed protection was studied in more detail using the availability of marker genes and mutants for defensesignaling pathways in A. thaliana. Some biocontrol agents, such as the fluorescent Pseudomonad CHA0, already induce these defenses before the arrival of the pathogen, providing induced or acquired resistance (Van Loon et al. 1998). Therefore, we com- 
pared our bacteria with CHA0-Rif, an established biocontrol agent with known modes of action, including direct antibiosis (Keel et al. 1992) and induction of systemic resistance (Iavicoli et al. 2003). Furthermore, it is beneficial for a pathogen to suppress defense responses after having been perceived by the plant to avoid induction of resistance (Staples and Mayer 2003). Oxalic acid might act by repressing or redirecting plant defenses (Cessna et al. 2000). Degradation of oxalic acid by ox-strains could derepress plant defenses and decrease disease, which would be reflected in the altered expression of defense genes and the requirement of intact defense pathways for protection.

\section{RESULTS}

Isolation and selection of oxalate-degrading bacteria.

The initial screening on Schlegel's Ca-oxalate plates yielded 42 halo-forming isolates. These were tested initially in a qualitative screening using cucumber-S. sclerotiorum and $A$. thaliana-S. sclerotiorum as pathosystems (data not shown). Strains that caused symptoms such as chlorosis or ectopic lesions were eliminated from further studies. We retained several oxalate-degrading strains that could grow well on common media and provide some protection against the known oxalate producer S. sclerotiorum. Four isolates, named ox-strain B, C, $\mathrm{D}$, and $\mathrm{E}$ (Table 1), grew well on the rich media Lennox-Luria broth (LB; Sigma-Aldrich, Buchs, Switzerland) and King's B (KB) agar (King et al. 1954), made halos on Schlegel's Caoxalate plates (Fig. 1), and showed medium to strong protection against $S$. sclerotiorum in a qualitative assay on cucumber and a reduction of disease symptoms by 20 to $41 \%$ on $A$. thaliana. These were used for all further studies, together with the established biocontrol strain Pseudomonas sp. CHA0-Rif as a control for disease suppression via other mechanisms than oxalate degradation.

\section{Characterization of oxalate-degrading bacteria.}

The sequencing of $16 \mathrm{~S}$ rDNA allowed identification of the ox-strains at genus level (Table 1), with the best hits always reaching a nucleotide identity of $99 \%$ or more. Alignment of the $16 \mathrm{~S}$ rDNA sequences with representative bacteria found in the National Center for Biotechnology Information database shows that all new ox-strains cluster with bacteria that already have been described as oxalate degraders (Supplementary Fig. 1). Ox-strain B belongs to the genus Cupriavidus (Vandamme and Coenye 2004), of which most members were recently reclassified from the genus Ralstonia or Wautersia, and is most related to Cupriavidus campinensis (Goris et al. 2001). Members of this genus are known for their ability to use a wide range of carbon sources, and it contains the oxalate-degrading bacterium $C$. oxalaticus (formerly Pseudomonas oxalaticus) (Khambata and Bhat 1953). Ox-strain $C$ is most related to Bacillus cereus and B. thuringensis; the Bacillus genus also contains the oxalate-degrading bacterium B. subtilis (Tanner et al. 2001). Both ox-strain D and E seem to be most related to Variovorax paradoxus (Willems et al. 1991). From the genus Variovorax, the ribosomal DNA of only a few isolates has been sequenced, thus limiting the determination of species. Also, $V$. paradoxus (formerly Alcaligenes paradoxus) is able to degrade oxalate (Willems et al. 1991).

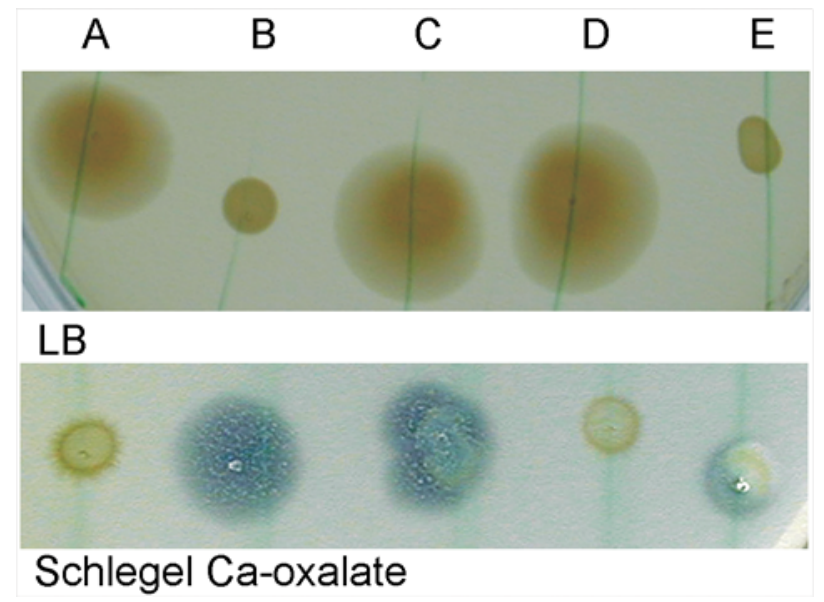

Fig. 1. Strain A (CHA0-Rif) grew on Lennox-Luria Broth (LB) but could not clarify the Ca-oxalate in Schlegel's medium with $\mathrm{Ca}$-oxalate as the sole carbon source. Ox-strain B, C, D, and E form colonies on LB and clarified zones in the Ca-oxalate. For strains D and E, the clarified zone remains restricted to the area underneath the colony (intermediately strong degraders) whereas, for strains $\mathrm{B}$ and $\mathrm{C}$, the clarified zone expanded beyond the edge of the colony (strong degraders).

Table 1. Characteristics of bacterial strains used in this study

\begin{tabular}{|c|c|c|c|c|c|c|c|}
\hline $\begin{array}{l}\text { Strain } \\
\text { code }\end{array}$ & Species & Isolate & Degrade $^{a}$ & $\begin{array}{l}\text { Fungitoxi } \\
\text { c activity }\end{array}$ & Reference & $\begin{array}{c}\text { Accession } \\
\text { number }\end{array}$ & Source \\
\hline A & Pseudomonas sp. ${ }^{\mathrm{c}}$ & CHA0-Rif & - & 6 & Natsch et al. 1994 & AJ697956 ${ }^{\mathrm{d}}$ & Agricultural soil, Switzerland \\
\hline \multirow[t]{2}{*}{ B } & Cupriavidus campinensis $^{\mathrm{c}}$ & $\mathrm{oxB}$ & + & 0 & This study & AJ697955 & \\
\hline & & & & & & AJ783977 & Rape rhizosphere, Switzerland \\
\hline $\mathrm{C}$ & Bacillus cereus ${ }^{\mathrm{c}}$ & oxC & + & 1 & This study & AJ697957 & Rape rhizosphere, Switzerland \\
\hline $\mathrm{D}$ & Variovarox spp. $^{\mathrm{c}}$ & oxD & + & 0 & This study & AJ697958 ${ }^{\mathrm{d}}$ & Rape rhizosphere, Switzerland \\
\hline E & Variovarox spp. $^{\mathrm{c}}$ & oxE & + & 0 & This study & AJ697959 ${ }^{d}$ & Rape rhizosphere, Switzerland \\
\hline \multirow[t]{2}{*}{$\mathrm{L}$} & C. basilensis & LMG 18990 & - & nd & Goris et al. 2001 & $\mathrm{AJ} 783973^{\mathrm{e}}$ & \\
\hline & & & & & & AJ783974f & Freshwater pond sediments, France \\
\hline M & C. campinensis & LMG 19282 & + & nd & Goris et al. 2001 & $\mathrm{AJ} 783975^{\mathrm{e}}$ & Zinc desert, Belgium \\
\hline $\mathrm{N}$ & C. campinensis & LMG 20576 & + & nd & Goris et al. 2001 & $\mathrm{AJ} 78397 \mathrm{f}^{\mathrm{e}}$ & Agricultural soil, Belgium \\
\hline \multirow[t]{2}{*}{$\mathrm{O}$} & C. necator $^{\mathrm{g}}$ & LMG 1201 & + & nd & Yabuuchi et al. 1995 & AJ783978 e & \\
\hline & & & & & & AJ783979f & Source sludge, Germany \\
\hline \multirow[t]{2}{*}{$\mathrm{P}$} & C. oxalaticus & LMG 2235 & + & nd & Sahin et al. 2000 & AJ783980 & \\
\hline & & & & & & AJ783981 ${ }^{\mathrm{f}}$ & Indian earthworm, India \\
\hline $\mathrm{Q}$ & Ralstonia picketii & LMG 5942 & - & nd & Yabuuchi et al. & AJ783972 e & Tracheotomy patient, United States \\
\hline
\end{tabular}

${ }^{a}$ In vitro oxalate degradation. Halo formation around bacterial colonies on Schlegel's minimal medium with Ca-oxalate as the sole carbon source.

${ }^{\mathrm{b}}$ Size of the inhibition zone $(\mathrm{mm})$ around bacterial agar plugs on a MEA plate seeded with Botrytis cinerea spores; nd = not determined.

${ }^{\mathrm{c}}$ Closest relative as determined by sequence comparison of the $16 \mathrm{~S}$ rDNA.

d Accession number of $16 \mathrm{~S}$ rDNA.

e Accession number of intergenic transcribed sequence (ITS) long sequence.

${ }^{\mathrm{f}}$ Accession number of ITS short sequence.

${ }^{g}$ Formerly known as Ralstonia eutropha or Wautersia eutropha. 
On solid Schlegel's medium with Ca-oxalate, ox-strains B to E, but not CHA0-Rif, formed clarified zones within 3 days after inoculation (Fig. 1), which expanded beyond the edge of the colony for ox-strain B and C. Expansion of the clarified zone around $\mathrm{D}$ and $\mathrm{E}$ required more time. Ox-strains $\mathrm{B}$ to $\mathrm{E}$, but not CHA0-Rif, could grow in liquid Schlegel's medium with potassium oxalate at $28^{\circ} \mathrm{C}$. At $84 \mathrm{~h}$ postinoculation (hpi), the oxalate concentration was reduced by only $7 \%$ for $\mathrm{CHA} 0$ Rif in contrast to a reduction by $38,54,36$, and $65 \%$ by oxstrains B, C, D, and E, respectively.

The new ox-strains do not produce significant amounts of fungitoxic compounds (Table 1). The ox-strains B, D, and E did not cause any inhibition zone in the in vitro antibiotic assay, ox-strain $\mathrm{C}$ gave an inhibition zone of approximately 1 $\mathrm{mm}$, and CHA0-Rif inhibited growth of $B$. cinerea in a zone of approximately $6 \mathrm{~mm}$, most likely as a result of production of 2,4-diacetyl phloroglucinol (DAPG) (Keel et al. 1992).

For better phylogenic placement of ox-strain B, we amplified and sequenced intergenic transcribed sequence (ITS) fragments from this bacterium and selected Cupriavidus and Ralstonia isolates (Table 1). Alignment of these ITS sequences confirms that ox-strain B is more closely related to C. campinensis (99.7\% sequence identity) than to the other isolates (89 to $94 \%$ identity). The isolates LMG18990, LMG1201, and LMG2235 yielded additional short ITS sequences. Ox-strain B was compared with other Cupriavidus isolates to determine whether the protective activity correlates with the ability to degrade oxalic acid or other traits (Table 1). Only ox-strain B, both $C$. campinensis isolates, $C$. necator, and $C$. oxalaticus are able to degrade $\mathrm{Ca}$-oxalate in vitro, which distinguishes them from C. basilensis and Ralstonia pickettii.

\section{Bioassays on cucumber, grapevine, and tomato.}

On detached tomato leaves, $B$. cinerea isolate B05.10 gave lesions of approximately $10 \mathrm{~mm} 4$ days postinoculation (dpi) and incubation at $20^{\circ} \mathrm{C}$ (Fig. 2A). On average, lesions caused by $B$. cinerea isolate BMM were $20 \%$ smaller than those caused by B05.10, and the percentage of outgrowing lesions was similar for both (approximately 90\%). Spraying with buffer alone slightly reduced average lesion size. Treatment with all five strains limited, but did not abolish, disease symptoms by reducing the number of outgrowing lesions and especially the lesion diameter (Fig. 2A), but only strains A, B, and $\mathrm{C}$ gave significant reduction in all three repetitions of the experiment for B05.10, and A and B for BMM.
On leaves of intact cucumber plants, treatment of both $B$. cinerea isolates yielded water-soaked lesions of approximately $9 \mathrm{~mm} 3$ dpi at $20^{\circ} \mathrm{C}$ (Fig. 2B). Treatment with buffer alone did not affect lesion size. Treatment with ox-strains limited disease symptoms by reducing the lesion diameter and especially the number of outgrowing lesions (Fig. 2B), but only strain A and $\mathrm{D}$ gave significant reduction in all three repetitions of the experiment. For strain D, the protection against BMM was not significant in all three repetitions, although it showed a trend of providing some protection. In one of the three repetitions, strain $\mathrm{C}$ followed the trend but displayed such large variation that the reduction in lesion size was not significant.

On detached leaves and inflorescences of grapevine, treatment with CHA0-Rif or ox-strain B could limit gray mold symptoms. On inoculated leaves, necrotic lesions appeared but were smaller on treated plants than on control leaves sprayed with buffer alone. On infected inflorescences, weight loss, discoloration, and abortion of flowers and petioles were strongly reduced upon treatment with ox-strain B (data not shown).

\section{Bioassays on Arabidopsis thaliana.}

On Arabidopsis thaliana Col-0 plants, both $B$. cinerea isolates gave water-soaked lesions (Fig. 3A) of approximately 12 $\mathrm{mm}$ in diameter at $3 \mathrm{dpi}$ at $20^{\circ} \mathrm{C}$ (Fig. 3B). On average, lesions caused by BMM were $20 \%$ smaller than those caused by B05.10 and the percentage of outgrowing lesions was similar for both (approximately 90\%). Spraying with buffer alone did not affect the lesion size. Treatment with all five strains limited, but did not abolish, disease symptoms by reducing the number of outgrowing lesions and especially the lesion diameter (Fig. 3B). Both B. cinerea isolates responded similarly to bacterial treatment; only results for B05.10 are shown in the following graphs. Similarly, inoculation of A. thaliana Col-0 plants with $S$. sclerotiorum gave water-soaked lesions of approximately $10 \mathrm{~mm}$ in diameter at $2.5 \mathrm{dpi}$ at $20^{\circ} \mathrm{C}$ (Fig. 3C). Treatment with all four ox-strains and especially CHA0-Rif limited, but did not abolish, disease symptoms by reducing the number of outgrowing lesions and their diameter (Fig. 3C).

The dependence of the ox-strains on plant-signaling pathways for effective protection was tested on A. thaliana lines (derived from Col-0) with defects in ET (etr1 and ein2-1), JA (jar1), and SA (NahG) signaling pathways. In most combinations, the bacteria still could give significant protection on these mutant lines (Fig. 4). Lesions on etr 1 and ein 2-1 plants were only marginally larger than on Col-0, and only protection
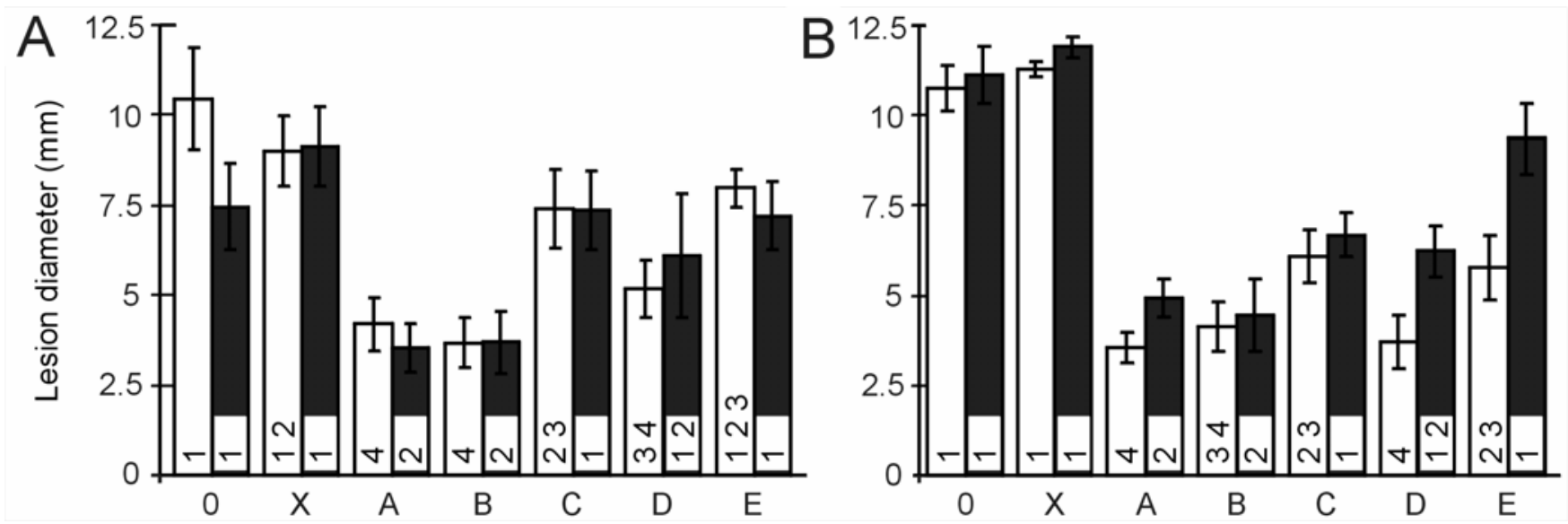

Fig. 2. Effect of CHA0-Rif and ox-strains on gray mold symptoms on A, tomato at 4 days postinoculation (dpi) and B, cucumber at 3 dpi. One day prior to inoculation with spores of Botrytis cinerea isolates B05.10 (white bars) and BMM (black bars), leaves were left untreated (0), sprayed with 10 mM potassium phosphate buffer, pH7.0 (X), or sprayed with bacteria of strains A, B, C, D, or E resuspended in potassium phosphate buffer at an optical density of 600 $\mathrm{nm}=0.6(\mathrm{~A}-\mathrm{E})$. Error bars indicate the standard error (SE) and different numbers in columns indicate statistically significant differences between treatments $(P=0.05, n=7)$. 
by ox-strain $\mathrm{B}$ and $\mathrm{D}$ was partially impaired on etr1. As expected, lesions on jar1 were larger than on Col-0; also, the protection provided by CHA0-Rif and ox-strains B and C was partially impaired. On NahG, lesions were slightly larger than on Col- 0 and only protection by ox-strain B was partially reduced. The mutant eds5, which also is impaired in SA signaling, yielded similar results as NahG plants (data not shown).

When A. thaliana Col-0 plants were sprayed with ox-strain $\mathrm{B}$ and related Cupriavidus strains, a protective effect against $B$. cinerea also could be observed for isolates LMG19282 and LMG20576 (C. campinensis), but not for LMG18990 (C. basilensis) (Table 2). In contrast to the $C$. campinensis strains and ox-strain $\mathrm{B}$, the $C$. basilensis strain is not able to degrade oxalic acid on Schlegel's Ca-oxalate plates (Table 2).

\section{Construction and characterization of transposon mutants.}

Electroporation of the transposon EZTN $<$ R6Krori_KAN-2 $>$ into ox-strain $\mathrm{C}$ and $\mathrm{E}$ did not yield any kanamycin-resistant colonies, which suggests that they are not easily transformed by this method. Electroporation of the transposon EZTN<
R6Krori_KAN-2> into ox-strain D yielded only eight kanamycin-resistant colonies, which all made normal clarified zones on Schlegel's Ca-oxalate plates.

Electroporation of this transposon into ox-strain B yielded many kanamycin-resistant colonies. In all, 2,000 colonies were transferred to 96-well plates with liquid $\mathrm{KB}$ and kanamycin at $15 \mathrm{ppm}$ and screened for reduced halo formation on Schlegel's $\mathrm{Ca}$-oxalate plates. We found seven mutants that were partially impaired in halo formation. Two putative mutants were discarded because they showed insufficient growth on plates with carbon sources other than oxalate (e.g., glucose and glycerol). The other mutants were able to form halos on Schlegel's Caoxalate plates only after prolonged incubation; they needed approximately 4 days more than the wild-type ox-strain B (2 to 3 days) to initiate oxalate degradation.

The insertion sites of the transposons were determined by plasmid rescue and sequencing of the flanking regions. Transposons were found to have inserted in or directly upstream of regions coding for shikimate 5-dehydrogenase (mutant 1-3), lysR transcriptional regulator (mutant 4-3), uncharacterized

A
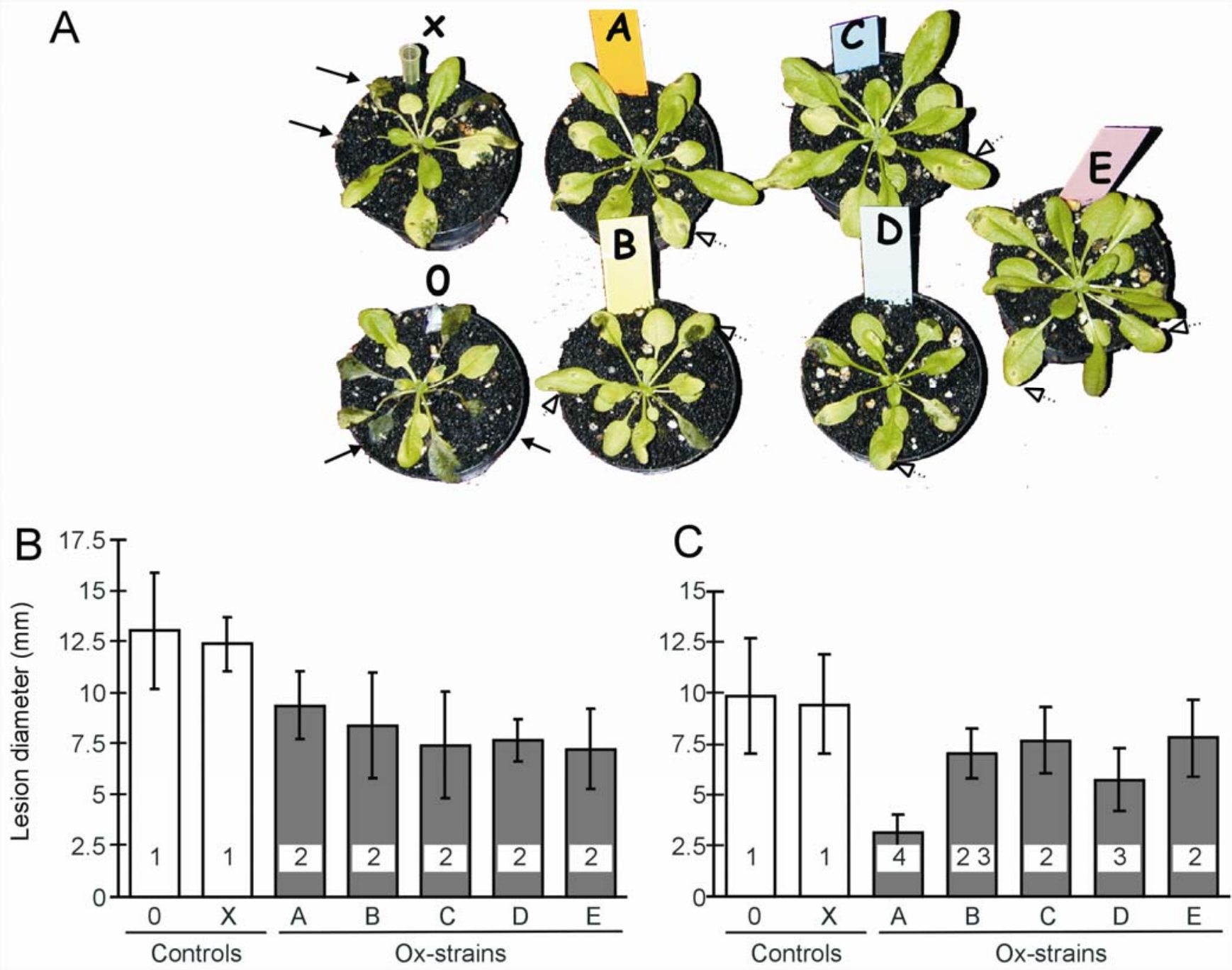

Fig. 3. Effect of CHA0-Rif and ox-strains on $\mathbf{A}$ and $\mathbf{B}$, gray mold and $\mathbf{C}$, white mold symptoms on Arabidopsis thaliana Col-0. On each plant, six leaves were inoculated with one droplet of spores of Botrytis cinerea isolates B05.10 (left of the middle vein) and BMM (right of the middle vein) or one droplet of Sclerotinia sclerotiorum mycelial fragments. Only upon successful infection did water-soaked lesions appear, A, resulting in rot of the entire untreated leaves within 5 days after $B$. cinerea inoculation (A). Arrows indicate fully degraded leaves, arrowheads indicate lesions with a reduced outgrowth. The diameter of lesions was measured at $\mathbf{B}, 3$ days postinoculation (dpi) for $B$. cinerea $\mathrm{B} 05.10$ and $\mathbf{C}, 2.5$ dpi for $S$. sclerotiorum. One day prior to inoculation, plants were left untreated (0), sprayed with $10 \mathrm{mM}$ potassium phosphate buffer, $\mathrm{pH} 7.0(\mathrm{X})$, or sprayed with bacteria of strains $\mathrm{A}, \mathrm{B}, \mathrm{C}, \mathrm{D}$, or E resuspended in potassium phosphate buffer at an optical density of $600 \mathrm{~nm}=0.6$ (A through E). Error bars indicate the standard error (SE) and different numbers in columns indicate statistically significant differences between treatments $(P=0.05, n=8)$. 
protein conserved in bacteria (mutant 5-4), methyl accepting chemotaxis protein (mutant 7-2), and Holliday junction resolvase (mutant 9-8). There are no inserts directly into enzymes known to be involved in oxalate degradation.

Protection assays on A. thaliana Col-0 plants showed that all transposon mutants are still able to confer a certain degree of protection against $B$. cinerea (Fig. 5A), but not as effectively as the wild-type ox-strain B. The mutants 5-4, 7-2, and 9-8 provided significantly less protection against $B$. cinerea on Col-0. On detached tomato leaves treated with the mutants, lesion sizes were between those of untreated leaves and leaves treated with ox-strain B (Fig. 5B). The mutants 1-3 and 5-4 provided protection that was not different from ox-strain $\mathrm{B}$; protection provided by $4-3,7-2$, and $9-8$ was significantly less than that by ox-strain B.

\section{Gene expression in A. thaliana.}

Most treatments with bacteria alone had little effect on expression of the marker genes $P R 1, P D F 1.2$, and AOS1 (Fig. 6). $P D F 1.2$ was induced by CHA0-Rif and weakly induced by oxstrain B and C. All treatments except ox-strain B weakly induced expression of AOS1.

Gene expression was studied in more detail after pretreatment with ox-strain B, with and without inoculation with B. cinerea. Quantification of gene expression after pretreatment with ox- strain B without inoculation with $B$. cinerea showed that $P D F 1.2$ and $P A D 3$ were moderately and $E R F 1$ and $A O S 1$ were weakly upregulated by the bacteria alone, but no induction was observed for $A C X 1$ and PRI (Supplementary Fig. 2). After in-

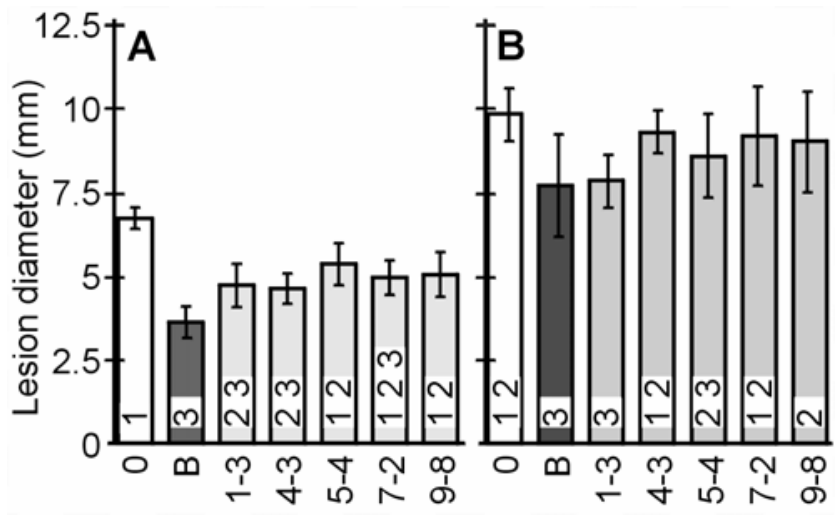

Fig. 5. Protection by ox-strain $B$ and derived transposon mutants against Botrytis cinerea $\mathrm{B} 05.10$ on A, Arabidopsis thaliana Col-0 and $\mathbf{B}$, tomato. Error bars indicate the standard error (SE) and different numbers in columns indicate statistically significant differences between treatments $(P=$ $0.05, n=8)$.

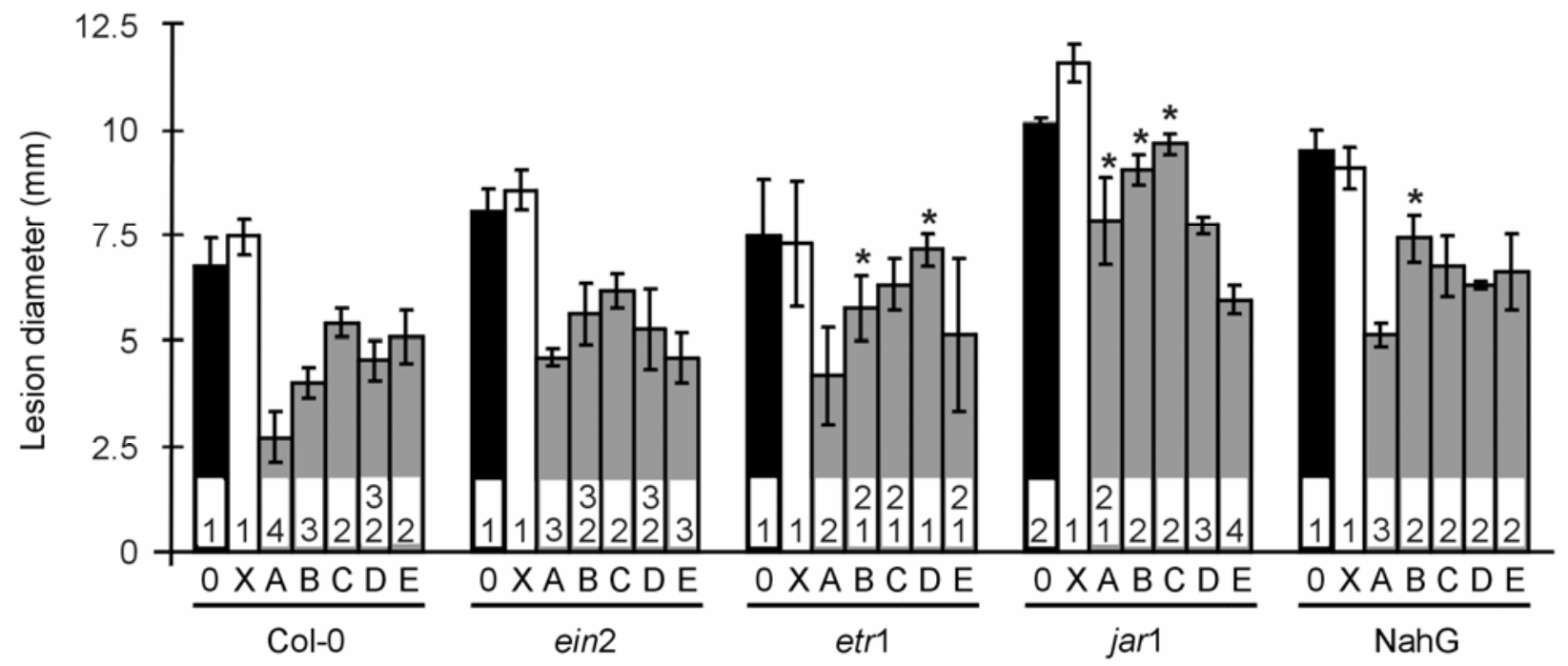

Fig. 4. Effect of CHA0-Rif and ox-strains on gray mold symptoms on Arabidopsis thaliana signaling mutants ein2, etr1, jar1, and NahG in the Col-0 background. One day prior to inoculation with spores of Botrytis cinerea isolate B05.10, leaves were left untreated (0), sprayed with $10 \mathrm{mM}$ potassium phosphate buffer, $\mathrm{pH} 7.0(\mathrm{X})$, or spayed with bacteria of strains $\mathrm{A}, \mathrm{B}, \mathrm{C}, \mathrm{D}$, or E resuspended in potassium phosphate buffer at an optical density of $600 \mathrm{~nm}=$ 0.6 (A-E). Error bars indicate the standard error (SE) and different numbers in columns indicate statistically significant differences between treatments within one $A$. thaliana line $(P=0.05, n=5)$. In columns marked with an asterisk (*) the efficacy of bacteria to protect on this line was significantly different from the efficacy on Col-0 $(P=0.05)$.

Table 2. Protection of Arabidopsis thaliana Col-0 against Botrytis cinerea isolates B05.10 and BMM by different Cupriavidus strains in relation to their ability to degrade oxalic acid

\begin{tabular}{|c|c|c|c|c|c|c|c|c|}
\hline \multirow[b]{2}{*}{ Treatment $^{\mathrm{a}}$} & \multicolumn{4}{|c|}{ B05.10 } & \multicolumn{4}{|c|}{ BMM } \\
\hline & Lesion size (mm) & $\mathbf{S E}^{\mathbf{b}}$ & Duncan $^{c}$ & Degrade $^{d}$ & Lesion size (mm) & $\mathbf{S E}^{\mathbf{b}}$ & Duncan $^{c}$ & Degrade $^{d}$ \\
\hline 0 & 6.86 & \pm 0.05 & 1 & $\ldots$ & 3.52 & \pm 0.24 & 1 & $\ldots$ \\
\hline buffer & 6.32 & \pm 0.49 & 1 & $\ldots$ & 3.02 & \pm 0.29 & 1 & $\ldots$ \\
\hline oxB & 4.86 & \pm 0.24 & 2 & + & 2.26 & \pm 0.21 & 2 & + \\
\hline $\mathrm{L}$ & 6.94 & \pm 0.39 & 1 & - & 3.20 & \pm 0.25 & 1 & - \\
\hline M & 4.05 & \pm 0.41 & 2,3 & + & 1.99 & \pm 0.25 & 2 & + \\
\hline $\mathrm{N}$ & 3.54 & \pm 0.50 & 3 & + & 1.85 & \pm 0.15 & 2 & + \\
\hline
\end{tabular}

${ }^{a}$ One day prior to inoculation with spores of $B$. cinerea, whole plants were left untreated (0), sprayed with $10 \mathrm{mM}$ potassium phosphate buffer, pH7.0 (buffer), or sprayed with bacteria resuspended in potassium phosphate buffer at an optical density at $600 \mathrm{~nm}=0.6$.

${ }^{\mathrm{b}} \mathrm{SE}=$ standard error.

${ }^{c}$ Different numbers in the same column indicate that lesion sizes are significantly different according to Duncan's analysis of variance $(P<0.05)$.

d Ability to degrade oxalic acid, measured as halo formation around bacterial colonies on Schlegel's minimal medium with Ca-oxalate as the sole carbon source. 
oculation with $B$. cinerea alone, all defense genes are induced and reach a maximum at $24 \mathrm{hpi}$ for $A C X 1, A O S 1, E R F 1$, $P A D 3$, and $P D F 1.2$, or 48 hpi for PR1. After the combined treatment with ox-strain $\mathrm{B}$ and $B$. cinerea, most genes, notably $A O S 1, P A D 3, P D F 1.2$, and $P R 1$, are induced more than in the single treatments at some time points. $P D F 1.2$ was induced stronger in the combined treatment than in the $B$. cinereaalone treatment at every time point.

\section{DISCUSSION}

Oxalate-degrading bacteria can provide partial protection of $A$. thaliana, tomato, cucumber, and grapevine against $B$. cinerea. This indicates that oxalic acid indeed contributes to the virulence of B. cinerea (Germeier et al. 1994; Prins et al. 2000) and is a valid target for disease control via disarmament, as proposed previously for $S$. sclerotiorum (Dickman and Chet 1998). The bacteria provide only partial protection to $B$. cinerea and are not able to completely prevent infection, probably because $B$. cinerea does not rely on oxalic acid as a sole pathogenicity factor (Prins et al. 2000). Furthermore, additional protective mechanisms such as antibiosis and plant defense activation might be active.

All bacterial isolates that were selected for their protective abilities turned out to have been isolated from the rhizosphere of either rape inoculated with $S$. sclerotiorum or broad-leaved dock. Both rhizosphere sites are probably rich in oxalate (Bohner 2001; Hatcher et al. 1997). The observation that bacteria isolated from rhizospheres provide better protection than those isolated directly from soil free of plant material gives a good indication that it is advantageous to use bacteria from plant-associated environments, because they most probably are more adapted to survival on plant surfaces. None of the isolates were from species of which the ability to degrade oxalate has been described (Table 1), but most are closely related to known oxalate degraders. This capability may not have been studied for many species and still be important in various niches and processes, such as nutrient cycling and weathering (Braissant et al. 2002; Sahin 2003). Previously described biocontrol bacteria also might deploy oxalate degradation as one of their "unknown" mechanisms. The Pseudomonas sp. CHA0-Rif does not degrade oxalic acid but employs DAPG for antibiosis and induction of plant defenses (Iavicoli et al. 2003; Keel et al. 1992). This al-

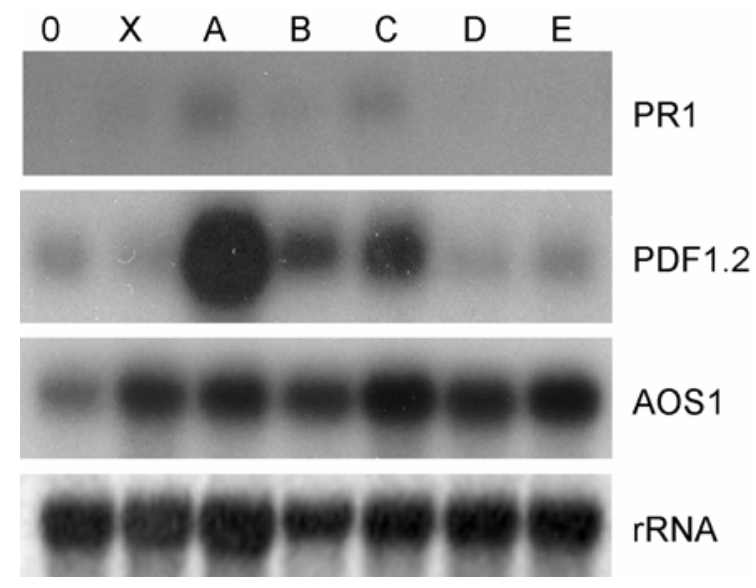

Fig. 6. Effect of CHA0-Rif and ox-strains on the expression of PR1, $P D F 1.2$, and AOS1, marker genes for salicylic acid-, ethylene-, and jasmonic acid-mediated resistance signaling pathways. Arabidopsis thaliana Col-0 plants were left untreated (0), sprayed with $10 \mathrm{mM}$ potassium phosphate buffer, pH7.0 (X), or sprayed with bacteria of strains A, B, C, $\mathrm{D}$, or E resuspended in potassium phosphate buffer at an optical density of $600 \mathrm{~nm}=0.6$ (A through E). Samples were taken $24 \mathrm{~h}$ after treatment. lows comparison of the protective mechanisms in the ox-strains with other mechanisms. None of the ox-strains produces significant amounts of antibiotics in an in vitro assay. Therefore, protection against pathogens by direct inhibition is unlikely.

Ox-strain B, the isolate showing the most consistent protection, belongs to the genus Cupriavidus and, most likely, the species $C$. campinensis. We found that not only $C$. oxalaticus (Khambata and Bhat 1953) but also the species $C$. campinensis and $C$. necator could degrade oxalate (Table 1 ), in contrast to the related species $C$. basilensis and $R$. pickettii. This oxalatedegrading capacity correlates with the ability to protect $A$. thaliana plants against $B$. cinerea. All oxalate-degrading $C$. campinensis isolates protect better than the closely related $C$. basilensis (Table 2), indicating that the protective abilities of ox-strains work, at least partially, via oxalate degradation. Other members of this genus are known for their versatile carbon metabolism (especially C. basilensis, C. campinensis, and $C$. necator) (Vaneechoutte et al. 2004) and resistance to (heavy) metals (notably $C$. basilensis, $C$. campinensis, and $C$. metallidurans) (Goris et al. 2001). They often are found in polluted sites where they contribute to degradation or containment of pollutants (Goris et al. 2001; Hanada et al. 1998). The possibility to use these bacteria in bioremediation of sites with organic or inorganic pollution or contamination is of current interest (Padilla et al. 2000; Roux et al. 2001). Survival in the presence of organic pesticides and copper would render oxstrain B advantageously compatible with agrochemicals used in chemical and biological control of plant diseases.

Mutagenesis of ox-strain $\mathrm{B}$ with the transposon EZTN $<$ R6K $\gamma$ ori_KAN-2 $>$ only yielded mutants that partially lost the ability to degrade oxalic acid, with an intermediate effect on protection (Fig. 5). It cannot be excluded that the transposon mutants have reduced survival on the plant surface; however, if the ability to degrade oxalic acid is the actual mechanism by which the ox-strains act, then it seems plausible that partial loss of degradation gives partial loss of protection. Surprisingly, the insertion sites of the transposons seem not to be involved in the direct degradation of oxalic acid. They have no significant homology with genes involved in bacterial oxalate degradation such as oxalyl-CoA-decarboxylases or oxalateformate antiporters (Svedruzic et al. 2005). Mutant 4-3, however, has an insertion in a gene for the transcriptional regulator LysR, which is involved in adaptation to other growth conditions and nutrient sources, as well as regulation of antibiotic production in Pseudomonas spp. (Lee and Cooksey 2000; Silby et al. 2005). The disruption of this gene may lengthen the time the bacteria need to adapt to new conditions and, hence, explain slower oxalate degradation and reduced protection. The mutant with the strongest reduction in protection, 72 , is mutated in a gene with homology to a gene for a "methylaccepting chemotaxis protein." This may be an indication that it is involved in perception of, and reaction to, the availability of external carbon sources, including oxalate.

The transposon insertions also may affect genes that are further away from the insertion site and affect oxalate degradation via these genes. Comparison of the insertion site with the partially sequenced genomes of the related bacteria $C$. necator and $C$. metallidurans showed that these regions contain genes with homology to acyl-CoA-transferases with a possible involvement in oxalate or subsequent formate metabolism (Heider 2001). This could be tested only by further sequencing and generation of targeted knockout mutants in $C$. campinensis.

Because we could exclude a role of direct antibiosis (Table 1) and could deduce that the ox-strains at least partially depend on oxalate degradation for protection (Fig. 5), we studied the contribution of plant defenses in the protective mechanism. Some plant-growth-promoting bacteria work by activating the plant 
defense responses via SA-, JA-, or ET-dependent pathways (Van Loon et al. 1998). Ox-strains could provide comparable or partially reduced levels of protection against $B$. cinerea on Col-0 and the $A$. thaliana mutant lines eds5, ein2-1, and jar1-2 (Fig. 4). The results observed here indicate that protection by none of the ox-strains is fully dependent on the SA-, ET-, or JA-signaling pathways. The data are in agreement with previous findings, where both JA and SA were shown to be involved in basal induced resistance to B. cinerea (Ferrari et al. 2003; McDowell and Dangl 2000; Van Loon et al. 1998). Only CHA0-Rif and oxstrains $\mathrm{B}$ and $\mathrm{C}$ were less effective on jar1-2 than on Col-0 (Fig. 4), corroborating the previous observation that CHA0-Rif can induce systemic resistance via the JA pathway (Iavicoli et al. 2003). It suggests that ox-strains $B$ and $C$ either activate or derepress plant defenses via the JA pathway.

The treatment with most ox-strains alone did not strongly induce PR1, PDF1.2, and AOS1, markers of the SA-, ET-, and JA-mediated resistance pathways, respectively (Fig. 6). This argues against direct activation of plant defenses by these bacteria. In a time-course experiment, induction of $P R 1, P D F 1.2$, $A O S 1$, and $P A D 3$ occurs faster or to a larger extent after treatment with ox-strain $\mathrm{B}$ in combination with $B$. cinerea than in case of the single treatments. Expression of $A C X 1, A O S 1$, and $P D F 1.2$, genes considered as markers for JA-mediated resistance, is differentially induced by pretreatment with ox-strain $\mathrm{B}$ in the presence or absence of $B$. cinerea. This indicates that the bacteria alone do not simply activate JA-mediated responses. The observed expression pattern partly resembles priming of defense genes, with the distinction that ox-strain $\mathrm{B}$ alone already induces $P A D 3, P D F 1.2$, and $P R 1$ but not $A C X 1$, AOS1, and $E R F 1$ whereas a priming treatment is defined as having no induction on its own (Conrath et al. 2006). The elevated plant defenses may be important for the protection, because the degradation of oxalic acid by the ox-strains probably causes derepression of plant responses. Oxalic acid is described to repress plant responses via a hitherto unknown mechanism and, thus, contribute to the virulence of $S$. sclerotiorum. In cell cultures of tobacco and soybean, the responses observed after treatment with various elicitors were strongly attenuated by addition of 4 to $5 \mathrm{mM}$ of oxalic acid (Cessna et al. 2000).

The observation that gray mold symptoms could be partially reduced by oxalate-degrading bacteria is another indication that, indeed, oxalate is involved in $B$. cinerea pathogenesis. This has been postulated before (Kunz et al. 2006; Prins et al. 2000), and currently is investigated by generating defined targeted mutants (J. van Kan and P. Tudzynski, personal communication). The evidence available indicates that oxalate functions as a supportive virulence factor, helping $B$. cinerea to broaden its host range (Germeier et al. 1994).

We have also demonstrated that interference with oxalic acid accumulation can be a useful strategy to control $B$. cinerea on various crop plants. It may be a target for new fungicides, which are dearly needed because $B$. cinerea continues to rapidly develop resistance to chemical control compounds with various modes of action (Rosslenbroich and Stuebler 2000). One alternative strategy would be to engineer crop plants with increased ability to degrade oxalic acid, using oxalate oxidase or oxalate decarboxylase genes. Oxalate oxidase seems to be involved in resistance of wheat and barley to fungal pathogens (Steiner-Lange et al. 2003; Zhang et al. 1995) and its overexpression can make crop plants more resistant to Sclerotinia spp. (Cessna et al. 2000; Donaldson et al. 2001; Thompson et al. 1995). The mechanism of resistance has not yet been elucidated; it could be the effect of reduction of oxalate concentrations to below phytotoxic levels, or the formation of $\mathrm{H}_{2} \mathrm{O}_{2}$ with antimicrobial and resistance-inducing properties. Another possibility is biocontrol by application of oxalate-degrading bacte- ria, for which the bacteria isolated in these studies provide a proof of concept. Further development requires optimization of oxalate-degrading capacity, colonization ability, and formulation and assessment of possible harm to other organisms (Paulitz and Belanger 2001; Walsh et al. 2001). This could be obtained by modification of available strains, maybe by mutation selection or overexpression of oxalate-degrading enzymes, once they are known. Otherwise, oxalate-degrading bacteria could be sought for on the surface of healthy host plants. The bacteria isolated in these studies offer a good starting point to develop biological control against $B$. cinerea by interference with oxalic acid accumulation.

\section{MATERIALS AND METHODS}

Chemicals were purchased from Sigma-Aldrich and media components were purchased from Difco (Sparks, MD, U.S.A.), unless stated otherwise.

\section{Isolation and selection of oxalate-degrading bacteria.}

Isolation of oxalate-degrading bacteria was based on the use of double-layer agar plates consisting of a base of Schlegel's minimal agar (Aragno and Schlegel 1992) (without carbon source) and an upper layer consisting of water agar $\left(18 \mathrm{~g} \mathrm{liter}^{-1}\right)$ and $\mathrm{Ca}$-oxalate at $7 \mathrm{~g} \mathrm{liter}^{-1}$, with oxalate as the unique carbon source. Ca-oxalate is hardly soluble in water and the upper layer is opaque. Oxalate-degrading bacteria solubilize this layer and, therefore, appear with a clear halo.

To obtain oxalate-degrading bacteria, we took samples from agricultural sites with a high probability to contain oxalic acid. At different locations in western Switzerland, rhizosphere soil was collected from the roots of broad-leaved dock (Rumex obtusifolius) (an oxalic-acid-producing plant) and rape (Brassica oleracea) (which can be infected by the oxalic-acid-producing fungus $S$. sclerotiorum). Different isolation strategies were used. First, direct isolation by extracting soil with sterile water followed by direct plating and screening on double-layer agar plates was used (Aragno and Schlegel 1992). In samples where this strategy did not yield any isolate, different enrichment strategies were applied: i) incubation of $1 \mathrm{~g}$ of soil in $50 \mathrm{ml}$ of liquid Schlegel's minimal medium with potassium oxalate as unique carbon source for 7 days or ii) sowing rape seed in a mix of soil and sclerotia of $S$. sclerotiorum. After 4 weeks of growth in the greenhouse, bacteria were isolated from the rhizosphere soil by extraction with sterile water. In both strategies, suspensions were diluted 10- or 100-fold and plated on double-layer agar plates. Plates were incubated for 3 to 21 days at $20^{\circ} \mathrm{C}$, developing colonies were picked and cultivated on one-fifth tryptic soy agar (TSA) plates (tryptic soy broth at $6 \mathrm{~g} \mathrm{liter}^{-1}$ and BactoAgar at $12 \mathrm{~g} \mathrm{liter}^{-1}$ ) (Oxoid, Basel, Switzerland) amended with cycloheximide at $195 \mathrm{mg} \mathrm{liter}^{-1}$, to avoid fungal growth. After a purifying step to obtain single colonies on one-fifth TSA containing either ampicillin or chloramphenicol to diminish growth of Actinomycetes, bacteria again were cultivated on the double-layer agar plates to confirm oxalate-degrading capacity.

Thus, 42 bacterial strains have been isolated. Five oxalatedegrading strains were kindly provided by Prof. M. Aragno (University of Neuchâtel, Neuchâtel, Switzerland). All these isolates were tested in a qualitative screening for their ability to provide protection against $S$. sclerotiorum on cucumber and A. thaliana. Four isolates were further characterized and used in subsequent plant protection assays (Table 1).

\section{Characterization of oxalate-degrading bacteria.}

All bacterial isolates (Table 1) could be grown routinely on $\mathrm{KB}$ medium (King et al. 1954) at $28^{\circ} \mathrm{C}$. The ox-strains B, C, 
$\mathrm{D}$, and $\mathrm{E}$ and $\mathrm{CHA} 0$-Rif were tested for growth in liquid Schlegel's medium with K-oxalate as the sole carbon source at $28^{\circ} \mathrm{C}$. The oxalate concentration remaining in the medium was measured after $84 \mathrm{~h}$ using a Boehringer oxalate kit (Roche, Basel, Switzerland). Bacteria were characterized on the basis of carbon-source usage with the API 50 CHE kit (BioMérieux, Marcy l'Etoile, France) and 16S rDNA sequencing (Amodia $\mathrm{GmbH}$, Braunschweig, Germany). For verification of bacterial isolates during experiments, polymerase chain reaction restriction fragment length polymorphism (PCR-RFLP) was employed as described previously (Wang et al. 2001), with minor modifications. Bacterial lysates were diluted 50-fold in sterile water and $4 \mu \mathrm{l}$ was used in a $50-\mu \mathrm{l} \mathrm{PCR}$ with redtaq (SigmaAldrich) to amplify the ITS of the rDNA region with the following primers: 16Sifwd (5'-TTGTACACACCGCCCGTC A-3') and 23Sirev (5'-GGTACCTTAGATGTTTCAGTTC-3'). Then, $8 \mu \mathrm{l}$ of each reaction was digested with $A l u \mathrm{I}, D d e \mathrm{I}$, MseI, or PvuII in $16 \mu \mathrm{l}$ of the appropriate buffer (NEB, Ipswich, MA, U.S.A.). Fragments were separated on a $2.5 \%$ agarose gel in $1 \times$ Tris-acetate EDTA.

Sequencing was performed by Microsynth AG (Balgach, Switzerland). Sequence comparisons were made by alignment and bootstrap analysis using ClustalX v1.8 (Thompson et al. 1997) and TreeView (Win32 v1.6.6 by R. D. M. Page, University of Glasgow, U.K.).

Direct antagonism of the ox-strains and CHA0-Rif was assessed by an in vitro antibiotic assay as described previously (Schoonbeek et al. 2002). In short, bacteria were incubated for either 4 or 24 days on plates with one-third strength potato dextrose agar (PDA) or one-fifth strength $\mathrm{KB}$ agar and agar plugs were transferred to half-strength malt extract agar plates (MEA) seeded with B. cinerea spores $\left(4 \times 10^{5} \mathrm{ml}^{-1}\right)$ or mycelial fragments from a liquid culture of $S$. sclerotiorum grown in potato dextrose broth (PDB) for $18 \mathrm{~h}$ at $22^{\circ} \mathrm{C}, 220$ rpm (6 $\mathrm{ml}$ in $50 \mathrm{ml}$ per plate). Antagonism was measured as inhibition zones around the bacterial agar plugs in the otherwise homogenous mycelial lawns. For each strain, only the size around agar plugs with the medium and age that yielded maximal inhibition is reported.

We focused more on ox-strain B because it routinely gives reproducible protection, can be grown easily on standard media, and belongs to a genus without any common pathogen, all of which are considered important features for application in biocontrol. Strains representative of species related to ox-strain B (Table 1) were ordered from the Belgian Coordinated Collections of Microorganisms (BCCM/LMG, Gent, Belgium), revived in the suggested media, and subsequently cultured in $\mathrm{KB}$ medium. The relation with ox-strain B was determined in more detail by comparison of the ITS sequences. These strains also were tested for their ability to use oxalate as a carbon source by spotting droplets on Schlegel's Ca-oxalate medium and observing growth and halo formation.

\section{Construction and characterization of transposon mutants.}

To find mutants with decreased oxalate-degrading activity, we screened a collection of mutants generated by insertional mutagenesis of the transposon EZTN $<$ R6Krori_KAN-2> (Epicentre, Madison, WI, U.S.A.) in the genome of oxalatedegrading bacteria.

Bacteria were made electrocompetent by repeated washing of cells from a fresh culture in LB (optical density at $600 \mathrm{~nm}$ $\left.\left[\mathrm{OD}_{600}\right]=0.8\right)$ with ice-cold water and resuspended in $10 \%$ glycerol $(\times 1,000$ concentrated $)$. Then, $100 \mu \mathrm{l}$ of bacteria were transformed by electroporation with a Genepulser II (Biorad, Hercules, CA, U.S.A.) with the following settings: pulse = $12.5 \mathrm{kV} / \mathrm{cm}$, voltage $=2.5 \mathrm{kV}$, resistance $=200 \Omega$, and capacitance $=50 \mu \mathrm{F}$. Transformed cells were mixed directly with
SOC medium (Sambrook et al. 1989), enriched with $2 \%$ glycerol, and incubated at $100 \mathrm{rpm}$ for $1.5 \mathrm{~h}$ at room temperature. Aliquots were plated on KB agar with kanamycin at $12.5 \mathrm{mg}$ liter $^{-1}$ and incubated for $36 \mathrm{~h}$ at $28^{\circ} \mathrm{C}$. Single colonies were transferred to duplicate 96-well plates with $100 \mu$ l of $\mathrm{KB}$ with kanamycin at $15 \mathrm{mg} \operatorname{liter}^{-1}$ and incubated for $72 \mathrm{~h}$ at $28^{\circ} \mathrm{C}$. One plate was used for storage at $-20^{\circ} \mathrm{C}$ after the addition of $100 \mu \mathrm{l}$ of $30 \%$ glycerol, and the other duplicate was used in a screening by replicate plating on KB agar and Schlegel's Caoxalate plates and incubated at $28^{\circ} \mathrm{C}$. Selected mutants were maintained on $\mathrm{KB}$ agar with kanamycin at $15 \mathrm{mg} \mathrm{liter}^{-1}$, and verified for reduced halo formation on Schlegel's Ca-oxalate plates. PCR-RFLP was employed to verify that all obtained mutants were derived from the ox-strain used for the mutagenesis.

Plasmid rescue was used for determination of the transposon insertion sites. Genomic DNA of the selected mutants was digested with EcoRI, self-ligated with T4 ligase, and electroporated into TransforMax EC100D pir-116 Escherichia coli cells according to the manufacturer's instructions (Epicentre).

\section{Culturing of plants and fungi.}

Seed of $A$. thaliana accession Columbia (Col-0) were purchased from Lehle Seeds (Round Rock, TX, U.S.A.). Col-0derived mutants in the ET-signaling pathway ein2-1 and etr1-1 were obtained from the Nottingham Arabidopsis Stock Center; the Col-0 mutants in the JA-signaling pathway jar1-2 was provided by P. E. Staswick (University of Nebraska, Lincoln, U.S.A.); and the transgenic line NahG impaired in SA signaling was provided by J. Ryals (Novartis, Research Triangle Park, NC, U.S.A.). A. thaliana plants were grown in individual pots $(5 \mathrm{~cm})$ as described previously (Nawrath and Métraux 1999). Cucumber and tomato plants were cultured on Arabidopsis soil amended with $25 \%$ peat. Cucumber plants ( $\mathrm{Cucu}$ mis sativus cv. Chinesische Schlange) were grown in individual pots $(10 \mathrm{~cm})$ for 4 weeks in a growth chamber at $20^{\circ} \mathrm{C}$ with a 12-h photoperiod. Tomato plants (Lycopersicon esculentum $\mathrm{cv}$. Moneymaker) were germinated in a growth chamber at $20^{\circ} \mathrm{C}$ with a 12 -h photoperiod, transplanted after 3 weeks to individual pots $(15 \mathrm{~cm})$, and transferred to a greenhouse with a $16-\mathrm{h}$ photoperiod. Grapevine plants (Vitis vinifera cv. Pinot Noir and Chasselas) were kindly made available by O. Viret (Swiss Federal Agricultural Research Station, Changins, Switzerland).

B. cinerea strains B05.10 (Buttner et al. 1994) and BMM (Zimmerli et al. 2001) were provided by J. van Kan (Wageningen University, Wageningen, The Netherlands) and B. MauchMani (University of Neuchâtel, Neuchâtel, Switzerland), respectively, and were cultured as described previously (Schoonbeek et al. 2002). S. sclerotiorum was obtained from a rapeseed field in western Switzerland, stored as dry sclerots, and cultured on PDA at $15^{\circ} \mathrm{C}$. The production of oxalic acid by these fungi was verified on half-strength MEA plates amended with $\mathrm{CaCO}_{3}\left(8 \mathrm{~g} \mathrm{liter}^{-1}\right)$ and the $\mathrm{pH}$ indicator bromocresol green (80 $\left.\mathrm{mg} \mathrm{liter}^{-1}\right)$ (Germeier et al. 1994).

\section{Bioassays on $A$. thaliana, cucumber, grapevine, and tomato.}

Plant protection assays were performed as described previously (Schoonbeek et al. 2002), with the following adaptations. For the production of $S$. sclerotiorum inoculum $1 \mathrm{~cm}^{2}$ of PDA with freshly grown mycelium was fragmented with a sterile scalpel and incubated in $20 \mathrm{ml}$ of half-strength PDB for $40 \mathrm{~h}$ at $180 \mathrm{rpm}$ and $20^{\circ} \mathrm{C}$. The mycelium was harvested by centrifugation for $5 \mathrm{~min}$ at $2,000 \mathrm{rpm}$ and resuspended in 15 $\mathrm{ml}$ of water. The mycelial aggregates were fragmented in a homogenizer (Polytron; Kinematica, Littau, Switzerland) by 
grinding at $11 \mathrm{krpm}$ for $1 \mathrm{~min}$ and $22 \mathrm{krpm}$ for $5 \mathrm{~s}$. For $A$. thaliana and cucumber, whole plants in single pots were used; for tomato and grapevine, detached leaves from multiple plants were placed on a grid with the petioles in wet tissue paper. Plants were sprayed with overnight cultures of bacteria in $\mathrm{KB}$ resuspended in $10 \mathrm{mM}$ potassium phosphate buffer $(\mathrm{pH} 7.0)$ to $\mathrm{OD}_{600}=0.6$ (approximately $3 \times 10^{9} \mathrm{CFU} \mathrm{ml}{ }^{-1}$ ) and inoculated the following day with $B$. cinerea or $S$. sclerotiorum. Plants were pairwise inoculated with at least six droplets of $2 \mu \mathrm{l}(5 \times$ $10^{5}$ spores $\mathrm{ml}^{-1}$ ) of the B. cinerea strains B05.10 and BMM, or six droplets of $5 \mu \mathrm{l}$ containing $S$. sclerotiorum mycelial fragments in fourfold-diluted PDB, and incubated in humid boxes for 3 or 4 days at $20^{\circ} \mathrm{C}$. Disease symptoms were measured as the lesion diameter of all inoculation sites. To compare the protective ability of bacterial treatments on different $A$. thaliana lines, we calculated the efficacy of a treatment using the following formula: $\mathrm{E}_{\text {treatment }}=\left(\left[\mathrm{D}_{\text {control }}-\mathrm{D}_{\text {treatment }}\right] / \mathrm{D}_{\text {control }}\right) \times$ $100 \%$, in which $\mathrm{E}_{\text {treatment }}$ is the efficacy of a certain treatment, $\mathrm{D}_{\text {control }}$ represents the average disease symptoms (lesion diameter) in the control treatment, and $\mathrm{D}_{\text {treatment }}$ represents the disease symptoms on each treated plant.

\section{Statistical evaluation.}

All experiments were performed at least three times. The absolute lesion sizes caused by $B$. cinerea varied between experiments, as expected for different batches of $B$. cinerea spores on different batches of plants at different seasons. Because the trend in protection was always similar, we showed only representative experiments. For statistical analysis, the average lesion size was first calculated per plant (A. thaliana) or leaf (cucumber, tomato, and grapevine) and the averages of at least six plants or leaves were presented. For the A. thaliana mutant lines, all treatments and inoculations were done with the same batches of bacteria and conidia but evaluation was performed individually for each mutant line. Differences between treatments were determined by analysis of variance followed by Duncan's multiple range test $(\alpha=0.05)$ using the statistical package SPSS (v11.0.1; SPSS Inc., Chicago).

\section{Gene expression in A. thaliana.}

The expression of marker genes for various plant-defense pathways in A. thaliana was studied by Northern blot analysis. A. thaliana Col-0 plants either untreated, mock-sprayed with phosphate buffer, or sprayed with phosphate buffer containing the ox-strains $\mathrm{A}, \mathrm{B}, \mathrm{C}, \mathrm{D}$, or $\mathrm{E}\left(\mathrm{OD}_{600}=0.6\right)$ were incubated for $24 \mathrm{~h}$ in a humid chamber. Samples were taken from three different plants per treatment and RNA was isolated and blotted as described previously (Nawrath and Métraux 1999). Membranes were hybridized with cDNA fragments of AOS1, $P D F 1.2$, and $P R 1$ labeled with $\left[\alpha-{ }^{32} \mathrm{P}\right] \mathrm{dCTP}$ using the PrimeA-Gene labeling kit (Promega Corp., Madison, WI, U.S.A.). As a control for equal loading, the rRNA was visualized by methylene blue staining.

The effect of ox-strain B on gene expression was studied in more detail because of its apparent dependence on the JA pathway. A. thaliana Col-0 plants were mock sprayed with phosphate buffer or sprayed with phosphate buffer containing the ox-strain B and incubated for $24 \mathrm{~h}$ in a humid chamber. Subsequently, the plants were inoculated by spraying with a suspension of $B$. cinerea conidia $\left(2.5 \times 10^{5}\right.$ spores $\mathrm{ml}^{-1}$ in one-quarter PDB). At 10, 16, 24, and 48 hpi, samples were taken from 12 different plants per treatment; RNA from two independent experiments was pooled prior to denaturation, loading on gel, and transfer to three exact replica blots. Membranes were hybridized separately in modified Church buffer (Church and Gilbert 1984) with cDNA fragments of Actin, ACX1, AOS1, ERF1, PAD3, PDF 1.2, and PR1. Membranes were stripped with boiling $1 \%$ sodium dodecyl sulfate. The signal for each band was quantified using a phosphorimager Storm 820 (Amersham Biosciences, Little Chalfont, Buckinghamshire, U.K.) and the quantification software ImageQuant TL (v2003.03; Amersham). After subtraction of the background signal from each blot, the signals for each band were normalized against the signal from the corresponding Actin band.

\section{ACKNOWLEDGMENTS}

This project was partially funded by the National Centre of Competence in Research (NCCR) Plant Survival, research program of the Swiss National Science Foundation and COST action 835. The authors would like to express their gratitude to J. Emmenegger of the Institut Agricole de Grangeneuve (Switzerland) for help with the isolation of S. sclerotiorum, E. Kozlowski for help with the isolation of the ox-strains, S. Schouten from Wageningen University (The Netherlands) for suggesting the use of transposon mutagenesis, and F. Stefanato for help with statistical analysis.

\section{LITERATURE CITED}

Aragno, M., and Schlegel, H. 1992. The mesophilic hydrogen-oxidizing (Knallgas) bacteria. Pages 344-384 in: The Prokaryotes. A Handbook on the Biology of Bacteria: Ecophysiology, Isolation, Identification, Applications, 2nd ed. A. Balows, H. Trüper, M. Dworkin, W. Harder, and K.-H. Schleifer, eds. Springer, Berlin, Heidelberg, New York.

Bohner, A. 2001. Physiologie und futterbaulicher Wert des Ampfers. Pages 39-44 in: 7. Alpenländisches Expertenforum zum Thema: "Bestandesführung und Unkrautregulierung im Grünland-Schwerpunkt Ampfer." Bundesanstalt für Alpenländische Landwirtschaft, Irdning, Austria.

Boland, G. J., and Hall, R. 1994. Index of plant hosts of Sclerotinia sclerotiorum. Can. J. Plant Pathol. Rev. Can. Phytopathol. 16:93-108.

Braissant, O., Verrecchia, E. P., and Aragno, M. 2002. Is the contribution of bacteria to terrestrial carbon budget greatly underestimated? Naturwissenschaften 89:366-370.

Buttner, P., Koch, F., Voigt, K., Quidde, T., Risch, S., Blaich, R., Bruckner, B., and Tudzynski, P. 1994. Variations in ploidy among isolates of Botrytis cinerea: implications for genetic and molecular analyses. Curr. Genet. 25:445-450

Cessna, S. G., Sears, V. E., Dickman, M. B., and Low, P. S. 2000. Oxalic acid, a pathogenicity factor for Sclerotinia sclerotiorum, suppresses the oxidative burst of the host plant. Plant Cell 12:2191-2199.

Church, G. M., and Gilbert, W. 1984. Genomic sequencing. Proc. Natl. Acad. Sci. U.S.A. 81:1991-1995

Conrath, U., Beckers, G. J. M., Flors, V., Garcia-Agustin, P., Jakab, G., Mauch, F., Newman, M. A., Pieterse, C. M. J., Poinssot, B., Pozo, M. J., Pugin, A., Schaffrath, U., Ton, J., Wendehenne, D., Zimmerli, L., and Mauch-Mani, B. 2006. Priming: getting ready for battle. Mol. PlantMicrobe Interact. 19:1062-1071.

Dickman, M. B., and Chet, I. 1998. Biodegradation of oxalic acid: A potential new approach to biological control. Soil Biol. Biochem. 30:1195-1197.

Dickman, M. B., and Mitra, A. 1992. Arabidopsis thaliana as a model for studying Sclerotinia sclerotiorum pathogenesis. Physiol. Mol. Plant Pathol. 41:255-263.

Donaldson, P. A., Anderson, T., Lane, B. G., Davidson, A. L., and Simmonds, D. H. 2001. Soybean plants expressing an active oligomeric oxalate oxidase from the wheat gf-2.8 (germin) gene are resistant to the oxalate-secreting pathogen Sclerotinia sclerotiorum. Physiol. Mol. Plant Pathol. 59:297-307.

Fallik, E., Grinberg, S., and Ziv, O. 1997. Potassium bicarbonate reduces postharvest decay development on bell pepper fruits. J. Hortic. Sci. 72:35-41.

Ferrari, S., Plotnikova, J. M., De Lorenzo, G., and Ausubel, F. M. 2003. Arabidopsis local resistance to Botrytis cinerea involves salicylic acid and camalexin and requires EDS4 and PAD2, but not SID2, EDS5 or PAD4. Plant J. 35:193-205.

Gabler, F. M., and Smilanick, J. L. 2001. Postharvest control of table grape gray mold on detached berries with carbonate and bicarbonate salts and disinfectants. Am. J. Enol. Vitic. 52:12-20.

Germeier, C., Hedke, K., and von Tiedemann, A. 1994. The use of pHindicators in diagnostic media for acid-producing plant-pathogens. Z Pflanzenkrankh. Pflanzenschutz J. Plant Dis. Prot. 101:498-507.

Godoy, G., Steadman, J. R., Dickman, M. B., and Dam, R. 1990. Use of mutants to demonstrate the role of oxalic acid in pathogenicity of Sclerotinia sclerotiorum on Phaseolus vulgaris. Physiol. Mol. Plant Pathol. 37:179-191. 
Goris, J., De Vos, P., Coenye, T., Hoste, B., Janssens, D., Brim, H., Diels, L., Mergeay, M., Kersters, K., and Vandamme, P. 2001. Classification of metal-resistant bacteria from industrial biotopes as Ralstonia campinensis sp. nov., Ralstonia metallidurans sp. nov. and Ralstonia basilensis Steinle et al. 1998 emend. Int. J. Syst. Evol. Microbiol. 51:1773-1782.

Hanada, S., Shigematsu, T., Shibuya, K., Eguchi, M., Hasegawa, T., Suda, F., Kamagata, Y., Kanagawa, T., and Kurane, R. 1998. Phylogenetic analysis of trichloroethylene-degrading bacteria newly isolated from soil polluted with this contaminant. J. Ferment. Bioeng. 86:539544

Hatcher, P. E., Paul, N. D., Ayres, P. G., and Whittaker, J. B. 1997. The effect of nitrogen fertilization and rust fungus infection, singly and combined, on the leaf chemical composition of Rumex obtusifolius. Funct. Ecol. 11:545-553.

Heider, J. 2001. A new family of CoA-transferases. FEBS (Fed. Eur. Biochem. Soc.) Lett. 509:345-349.

Iavicoli, A., Boutet, E., Buchala, A., and Métraux, J. P. 2003. Induced systemic resistance in Arabidopsis thaliana in response to root inoculation with Pseudomonas fluorescens CHA0. Mol. Plant-Microbe Interact. 16:851-858

Jarvis, W. R. 1977. Botryotinia and Botrytis species: taxonomy, physiology, and pathogenicity: a guide to the literature, vol. 15. Canada Department of Agriculture, Harrow, Ontario, Canada.

Jones, D. L. 1998. Organic acids in the rhizosphere-a critical review. Plant Soil 205:25-44.

Keel, C., Schnider, U., Maurhofer, M., Voisard, C., Laville, J., Burger, U., Wirthner, P., Haas, D., and Defago, G. 1992. Suppression of root diseases by Pseudomonas fluorescens CHA0: Importance of the bacterial secondary metabolite 2,4-diacetylphloroglucinol. Mol. Plant-Microbe Interact. 5:4-13.

Khambata, S. R., and Bhat, J. V. 1953. Studies on a new oxalate decomposing bacterium, Pseudomonas oxalaticus. J. Bacteriol. 66:505-507.

King, E. O., Ward, M. K., and Raney, D. E. 1954. Two simple media for the demonstration of pyocyanin and fluorescein. J. Lab. Clin. Med. 44:301-307.

Kunz, C., Vandelle, E., Rolland, S., Poinssot, B., Bruel, C., Cimerman, A., Zotti, C., Moreau, E., Vedel, R., Pugin, A., and Boccara, M. 2006. Characterization of a new, nonpathogenic mutant of Botrytis cinerea with impaired plant colonization capacity. New Phytol. 170:537-550.

Lee, S. W., and Cooksey, D. A. 2000. Genes expressed in Pseudomonas putida during colonization of a plant-pathogenic fungus. Appl. Environ. Microbiol. 66:2764-2772

Livingstone, D. M., Hampton, J. L., Phipps, P. M., and Grabau, E. A. 2005. Enhancing resistance to Sclerotinia minor in peanut by expressing a barley oxalate oxidase gene. Plant Physiol. 137:1354-1362.

Manteau, S., Abouna, S., Lambert, B., and Legendre, L. 2003. Differential regulation by ambient $\mathrm{pH}$ of putative virulence factor secretion by the phytopathogenic fungus Botrytis cinerea. FEMS (Fed. Eur. Microbiol. Soc.) Microbiol. Ecol. 43:359-366.

McDowell, J. M., and Dangl, J. L. 2000. Signal transduction in the plant immune response. Trends Biochem. Sci. 25:79-82.

Natsch, A., Keel, C., Pfirter, H. A., Haas, D., and Defago, G. 1994. Contribution of the global regulator gene GacA to persistence and dissemination of Pseudomonas fluorescens biocontrol strain CHA0 introduced into soil microcosms. Appl. Environ. Microbiol. 60:2553-2560.

Nawrath, C., and Métraux, J. P. 1999. Salicylic acid induction-deficient mutants of Arabidopsis express $P R-2$ and $P R-5$ and accumulate high levels of camalexin after pathogen inoculation. Plant Cell 11:13931404.

Padilla, L., Matus, V., Zenteno, P., and Gonzalez, B. 2000. Degradation of 2,4,6-trichlorophenol via chlorohydroxyquinol in Ralstonia eutropha JMP134 and JMP222. J. Basic Microbiol. 40:243-249.

Paulitz, T. C., and Belanger, R. R. 2001. Biological control in greenhouse systems. Annu. Rev. Phytopathol. 39:103-133.

Prins, T. W., Tudzynski, P., von Tiedemann, A., Tudzynski, B., Ten Have, A., Hansen, M. E., Tenberge, K., and Van Kan, J. A. L. 2000. Infection strategies of Botrytis cinerea and related necrotrophic pathogens. Pages 33-64 in: Fungal Pathology. J. W. Kronstad, ed. Kluwer Academic Publishers, Dordrecht, The Netherlands.

Rollins, J. A., and Dickman, M. B. 2001. pH signaling in Sclerotinia sclerotiorum: Identification of a pacC/RIM1 homolog. Appl. Environ. Microbiol. 67:75-81.

Rosslenbroich, H. J., and Stuebler, D. 2000. Botrytis cinerea-history of chemical control and novel fungicides for its management. Crop Prot. 19:557-561

Roux, M., Sarret, G., Pignot-Paintrand, I., Fontecave, M., and Coves, J.
2001. Mobilization of selenite by Ralstonia metallidurans CH34. Appl. Environ. Microbiol. 67:769-773.

Sahin, N. 2003. Oxalotrophic bacteria. Res. Microbiol. 154:399-407.

Sahin, N., Isik, K., Tamer, A. U., and Goodfellow, M. 2000. Taxonomic position of "Pseudomonas oxalaticus" strain Ox1(T) (D5M 1105(T)) (Khambata and Bhat, 1953) and its description in the genus Ralstonia as Ralstonia oxalatica comb. nov. Syst. Appl. Microbiol. 23:206-209.

Sambrook, J., Fritsch, E. F., and Maniatis, T. 1989. Molecular Cloning: A Laboratory Manual, 2nd ed. Cold Spring Harbor Laboratory Press, Cold Spring Harbor, NY, U.S.A.

Schoonbeek, H., Raaijmakers, J. M., and De Waard, M. A. 2002. Fungal $\mathrm{ABC}$ transporters and microbial interactions in natural environments. Mol. Plant-Microbe Interact. 15:1165-1172.

Silby, M. W., Giddens, S. R., and Mahanty, H. K. 2005. Mutation of a LysR-type regulator of antifungal activity results in a growth advantage in stationary phase phenotype in Pseudomonas aureofaciens PA147-2. Appl. Environ. Microbiol. 71:569-573.

Staples, R. C., and Mayer, A. M. 2003. Suppression of host resistance by fungal plant pathogens. Isr. J. Plant Sci. 51:173-184

Steiner-Lange, S., Fischer, A., Boettcher, A., Rouhara, I., Liedgens, H., Schmelzer, E., and Knogge, W. 2003. Differential defense reactions in leaf tissues of barley in response to infection by Rhynchosporium secalis and to treatment with a fungal avirulence gene product. Mol. Plant-Microbe Interact. 16:893-902.

Stewart, C. S., Duncan, S. H., and Cave, D. R. 2004. Oxalobacter formigenes and its role in oxalate metabolism in the human gut. FEMS (Fed. Eur. Microbiol. Soc.) Microbiol. Lett. 230:1-7.

Svedruzic, D., Jonsson, S., Toyota, C. G., Reinhardt, L. A., Ricagno, S., Lindqvist, Y., and Richards, N. G. 2005. The enzymes of oxalate metabolism: unexpected structures and mechanisms. Arch. Biochem. Biophys. 433:176-192

Tanner, A., Bowater, L., Fairhurst, S. A., and Bornemann, S. 2001. Oxalate decarboxylase requires manganese and dioxygen for activity-overexpression and characterization of Bacillus subtilis YvrK and YoaN. J. Biol. Chem. 276:43627-43634.

Thompson, C., Dunwell, J. M., Johnstone, C. E., Lay, V., Ray, J., Schmitt, M., Watson, H., and Nisbet, G. 1995. Degradation of oxalic acid by transgenic oilseed rape plants expressing oxalate oxidase. Euphytica 85:169-172.

Thompson, J. D., Gibson, T. J., Plewniak, F., Jeanmougin, F., and Higgins, D. G. 1997. The ClustalX windows interface: flexible strategies for multiple sequence alignment aided by quality analysis tools. Nucleic Acids Res. 24:4876-4882.

Van Loon, L. C., Bakker, P. A. H. M., and Pieterse, C. M. J. 1998. Systemic resistance induced by rhizosphere bacteria. Annu. Rev. Phytopathol. 36:453-483.

Vandamme, P., and Coenye, T. 2004. Taxonomy of the genus Cupriavidus: a tale of lost and found. Int. J. Syst. Evol. Microbiol. 54:2285-2289.

Vaneechoutte, M., Kampfer, P., De Baere, T., Falsen, E., and Verschraegen, G. 2004. Wautersia gen. nov., a novel genus accommodating the phylogenetic lineage including Ralstonia eutropha and related species, and proposal of Ralstonia [Pseudomonas] syzygii (Roberts et al. 1990) comb. nov. Int. J. Syst. Evol. Microbiol. 54:317-327.

Walsh, U. F., Morrissey, J. P., and O'Gara, F. 2001. Pseudomonas for biocontrol of phytopathogens: from functional genomics to commercial exploitation. Curr. Opin. Biotechnol. 12:289-295.

Wang, C. X., Ramette, A., Punjasamarnwong, P., Zala, M., Natsch, A., Moenne-Loccoz, Y., and Defago, G. 2001. Cosmopolitan distribution of phlD-containing dicotyledonous crop-associated biocontrol Pseudomonads of worldwide origin. FEMS (Fed. Eur. Microbiol. Soc.) Microbiol. Ecol. 37:105-116.

Willems, A., Deley, J., Gillis, M., and Kersters, K. 1991. Comamonadaceae, a new family encompassing the acidovorans ribosomal RNA complex, including Variovorax paradoxus Gen-Nov, Comb-Nov, for Alcaligenes paradoxus (Davis 1969). Int. J. Syst. Bacteriol. 41:445-450.

Yabuuchi, E., Kosako, Y., Yano, I., Hotta, H., and Nishiuchi, Y. 1995. Transfer of 2 Burkholderia and an Alcaligenes species to Ralstonia Gen-Nov-Proposal of Ralstonia pickettii (Ralston, Palleroni and Doudoroff 1973) Comb-Nov, Ralstonia solanacearum (Smith 1896) CombNov and Ralstonia eutropha (Davis 1969) Comb-Nov. Microbiol. Immunol. 39:897-904.

Zhang, Z. G., Collinge, D. B., and Thordal-Christensen, H. 1995. Germinlike oxalate oxidase, a $\mathrm{H}_{2} \mathrm{O}_{2}$-producing enzyme, accumulates in barley attacked by the powdery mildew fungus. Plant J. 8:139-145.

Zimmerli, L., Métraux, J. P., and Mauch-Mani, B. 2001. $\beta$-Aminobutyric acid-induced protection of Arabidopsis against the necrotrophic fungus Botrytis cinerea. Plant Physiol. 126:517-523. 